\title{
SHARI'AH AUDITING: A REVIEW OF SHARI'AH AUDIT PRACTICES IN ISLAMIC FINANCIAL INSTITUTION (IFIs)
}

\author{
Azwan Abdul Rashid, Masdiah Abdul Hamid*, Ahmad Subhi Mohamad Sidek, Wan \\ Mohammad Taufik Wan Abdullah, Inaliah Mohd Ali \\ Department of Accounting, Universiti Tenaga Nasional, Pahang, Malaysia.
}

\begin{abstract}
With its increasing number of Islamic Financial Institutions (IFIs) in the country, Malaysia has emerged as a leading hub when benchmarked against the other Islamic countries of the world. Unlike its conventional counterpart, the Islamic financial system focuses on the achievement of societal justice as evaluated within its own framework and uses its own criteria in order to achieve the objective of the Maqasid Ash-Shari'ah. To help achieve this objective, the Islamic finance industry is in need of Shari' $a h$ auditors who are not only knowledgeable and competent in ensuring that the IFIs operate in accordance with Shari'ah principles, but also adequate in supply, in order to cater for the increasing number of IFIs in the country. Therefore, a major aim of this study is to conduct a comprehensive review of the auditing process performed by Shari'ah auditors in determining the achievement of the Maqasid Ash-Shari'ah by the IFIs. Another aim of this study is to assess the existing Shari'ah auditing framework and standards practiced by IFIs in Malaysia. The results of this study could serve as a reference point for the regulatory and professional bodies in assessing the implementation of a comprehensive Shari'ah auditing framework.
\end{abstract}

Keywords: Shari'ah Auditing, Maqasid Ash-Shari'ah, Shari'ah Auditing Framework and Islamic Financial Institution

\section{INTRODUCTION}

The introduction of the Shari'ah Governance Framework (SGF) for Islamic Financial Institutions by Bank Negara Malaysia (BNM) on 1 January 2011 has brought immediate attention to both academicians and practitioners alike on the importance of Shari'ah governance. A major challenge for Shari'ah auditors toward the implementation of the SGF is the requirement for the auditor to possess adequate knowledge of Shari'ah to ensure that Islamic Financial Institutions (IFIs) operate in accordance with Shari'ah principles. According to Yaacob and Donglah (2012) the Islamic finance industry has grown at a rate of between $15 \%-20 \%$, a rate easily exceeding the world economic growth rate. It is therefore of crucial importance that Shari'ah auditors are able to play their role in ensuring that activities and operations carried out by the Islamic finance industry are subject to proper checks and balances and that their reporting is in line with Shari'ah principles. The presence of an auditor is perceived as fundamental for the quality of financial reporting and is an important element in the process of securing corporate accountability. From a conventional 
auditing perspective, the auditor is required to critically examine and evaluate whether the financial statements are prepared in accordance with GAAP and any relevant financial reporting framework. On the other hand, Shari'ah auditing of IFIs requires the Shari'ah auditor ensure that management is not only fully adhering with GAAP and with the relevant reporting framework, but also ensure that management follow the Shari'ah framework to ensure a sound and effective internal control system accordance with Shari'ah principles in achieving the ultimate objective of Shari'ah (Yaacob \& Donglah, 2012). The Shari'ah auditor is not only required to conduct a review of IFI activities in accordance with Shari'ah principles; he is also responsible for expressing his opinion on the IFI financial statements (AAOIFI, 2004; Mohammed Sarea \& Mohd Hanefah, 2013). To perform his auditing role effectively, a Shari'ah auditor should possess adequate and appropriate Islamic knowledge (AAOIFI, 2004). Yaacob and Donglah (2012) argues that a Shari'ah auditor has a similar role to that of the Muhtasib (Hisbah member), a role that is related to the concept of Taklif (accountability and responsibility) in ensuring that the IFIs strictly follow Shari'ah guidelines.

The existence of modern Islamic institution globally is over 50 years (Yaacob, 2012). The development of IFIs is purpose to provide benefit and value for society. In line with conventional development, people have realised that traditional method is not enough for them to capture the real activities of the business. Contradict with traditional system; Islamic system has captured a new dimension for society to perceive the value of accountability. Thus, proper auditing system in Islamic view is a basis for the IFIs to achieve their main objective in achieving the Maslahah to the Ummah. However, the absence of proper Shari'ah guidelines and standards is a major problem facing the current Shari'ah auditing framework (Kasim, Ibrahim, Hameed, \& Sulaiman, 2009). Additionally, lack of system pertaining to Shari'ah auditing also contribute to the failure of IFIs system in Malaysia. Therefore, regular independent Shari'ah audit in IFIs are necessary as people are now experiencing a movement along a continuum from a society that trust everything and audit nothing to a society that trust nothing and audit everything. In other words, regular independent Shari'ah audit in IFIs perceived as a vital part in order to achieve the ultimate objective of Shari'ah. Thus, this study aims to evaluate the Shari'ah auditing practices of Shari'ah auditors in IFIs in achieving the objectives of the Shari'ah.

\section{PROBLEM STATEMENT}

The rapid growth of the Islamic finance industry has led to an increase in demand for high quality Shari'ah auditing services from IFIs and the Muslim public who do business with them. Unlike its conventional counterpart, the Islamic finance industry is based on interest-free (riba-free) lending and borrowing activities where risks are shared between lender and borrower. Thus, the Islamic system is one that focuses on the promotion of social justice in order to achieve the objective of Maqasid Ash-Shariah on which its formation is based (Kassim, 2009). Towards the fulfilment of this objective, it is therefore vital for the Shari'ah auditors who audit the IFIs to be able to provide assurance and attestation that the IFIs are operated in accordance with Shari'ah principles. Compliance with Shari'ah principles, whether real or perceived, is therefore seen as an important consideration for the IFIs in order to earn the Muslim's trust and confidence in its products and services (Rahman, 2008). Therefore, it is important for IFIs to achieve its ultimate objective which 
is not contradicted to the fatwa, guidelines and instruction issued by the Fatwa and Shari'ah Supervisory Board (SSB) of the institution. Successful of IFIs operations with full compliance to the Shari'ah rules heavily depends on the structure of management control in the organisation. A high value of integrity and accountability to achieve Shari'ah objectives by reflecting with its economic activities is a key for the Islamic finance successful through proper check and balance. In other words, fully adhered with the Shari'ah rules and fatwa with the principle for the society justices are not easy task for IFIs to be achieved. Kassim (2009) argues that the practice of Shari'ah auditing has not been seriously taken by IFIs in Malaysia and resulting to the failure of IFIs in achieving their objectives. This may indicate that the management of IFIs lacked an adequate understanding of the Shari'ah auditing framework. Additionally, Yahya and Mahzan (2012) reported the Shari'ah practices of IFIs in Malaysia are still at the lower stage and that it is necessary for regulators to promote a Shari'ah audit.

A big challenge facing the external auditor when asked to carry out work on Shari'ah auditing is their current lack of knowledge and expertise on matters related to the Shari'ah. The role of Shari'ah auditor does not only include providing assurance to management and shareholders that the IFIs are run in accordance with the Shari'ah, but that they also have a responsibility to the Muslim (society as a whole) in helping to maintain the upkeep of Islamic values. Importantly, the Shari'ah auditor could help to play a role in influencing others because his religious knowledge of the Shari'ah is highly regarded and is expected to be in accordance with the Al-Quran, Sunnah and Ijma'. Thus, with his high Islamic knowledge of the Shari'ah, the Shari'ah auditor could assist IFIs in achieving their objectives. However, recent studies observe that there is a gap between the desired and the actual practices of Shari'ah auditing which suggest that IFIs in Malaysia do not seriously implement and fulfill the Shari'ah requirement in their business operations. A possible reason for this gap is that the management of IFIs in Malaysia is not clear on the scope of the Shari'ah auditing framework. Another possible reason for this gap is that the Shari'ah auditors are themselves lacking in the knowledge required to successfully carry out an audit in accordance with Shari'ah principles. Thus, adequate knowledge of the Shari'ah is a prerequisite for the successful performance of the Shari'ah auditing process. This indicates that the implementation of Shari'ah auditing is not an easy task for the Shari'ah auditor even studies find that the implementation of Shari'ah audit framework is considered relevant in order to cater the growing numbers of IFIs in Malaysia. The implementation of Shari'ah audit framework is very important because it's covered all aspects including governance, competency, processes and reporting system requirements of IFIs. However, without proper structure in Shari'ah auditing process, it will be difficult for IFIs to fulfill the Maslahah to the Ummah (benefit to the people) through socio-economic justice (Kasim et al., 2009) and further achieving of Maqasid Ash-Shari'ah. Hence, following the problems discussed above, the research question of this study as follow; to what extent the Shari'ah auditors do examination on the financial reporting and business operation of IFIs?

\section{Shariah Audit Practices}

Over the past decades, the auditing profession has come under increased scrutiny about the credibility of the auditor in examining the financial reporting. The biggest collapse and failure of giant corporation in USA have increased attention of many people including investors on the relying of financial reporting, decision making and more concern of corporate governance issues. 
Thus, public start to evaluate the auditor's work in fraud detection, reducing the manipulation issues and re-assess the level of trust they put on audit to provide assurance and ensure the company's activities reflect with the economic activities. Consequently, public has reduce confidence on the work of auditors and financial reporting. Accordingly, auditing profession has comes out with more guidelines and framework on professional skepticism in order to re-attract a public confident to the profession as a whole. Haniffa (2010) viewed the auditor as important person who live in central of human activities to protect and improve the condition of human life in all dimension. Therefore, the limited scope of conventional auditing framework which focused on the assurance and attestation services is realized and the movement to the Islamic based are necessary and viewed from different perspectives. Islam is concerned on the Islamic values because it reflects to the accountability and justice not only for society (Ummah), but also ultimately to Allah. As Allah said in the Holy Quran:

"O you who believe, why do you say that which you do not do? Grievously odious is it in the sight of Allah that you say that which you do not do".

(Surah As-Saff, 61:2-3)

The existence of IFIs seemed as a new dimension for the auditor since the wider of scope on the audit process including the compliance with Islamic guidelines is the key element for IFIs to achieve Maqasid Ash-Shari' ah instead of relying on the conventional auditing framework for audit purposes. The presence of Shari'ah auditor in the IFIs enables them to assist Muslims as the whole through their socio-economic justice and to the IFIs itself throughout the compliance of Shari'ah requirement. Kasim et al. (2009) claimed that the Shari'ah auditor capabilities in auditing IFIs because of wider scope should be focused. Therefore, a Shari'ah auditor should knowledgeable in Shari'ah and competent in order to reflect with the significant growth in Islamic finance. Apparently, the Shari'ah auditor is not only knowledgeable in accounting, auditing and finance, but must have a good knowledge in Shari'ah and Fiqh (Yaacob, 2012).

\section{CONCLUSION}

It is important to note that the processes of Islamic Financial Institutions (IFIs) and the practices of Shari'ah auditing clearly identified to minimise the gap and evaluate the obstacles in conducting the Shari'ah audit. Apart from that, the competency of Shariah auditor seems as important factor to assess their ability and successful of Shariah auditing. Additional skills and knowledge especially in Fiqh' Muamalat could enhance the independence and reliability of the shariah auditor in performing the shariah audit in IFIs.

\section{ACKNOWLEDGEMENTS}

We appreciate the research support given by the Universiti Tenaga Nasional (UNITEN), under the UNITEN Research Grant (UNITEN Internal Grant, Job No. J510050568). 


\section{REFERENCES}

AAOIFI. (2004). Accounting, Auditing and Governance Standards for Islamic Financial Institutions: Accounting and Auditing Organization for Islamic Financial Institutions Bahrain.

Haniffa, R. (2010). Auditing Islamic financial institutions. Islamic Finance: Instruments and Markets (QFinance), Bloomsbury, London.

Kasim, N., Ibrahim, M., Hameed, S., \& Sulaiman, M. (2009). Shariah auditing in Islamic financial institutions: exploring the gap between the" desirable" and the" actual". Global Economy \& finance journal, 2(2), 127-137.

Kassim, N. (2009). Dynamics of Shariah Auditing in Islamic Institutions: a study of the Malaysian Islamic financial sector. Unpublished thesis, International Islamic University Malaysia.

Mohammed Sarea, A., \& Mohd Hanefah, M. (2013). The need of accounting standards for Islamic financial institutions: evidence from AAOIFI. Journal of Islamic Accounting and Business Research, 4(1), 64-76.

Rahman, A. R. A. (2008). Shari'ah audit for Islamic financial services: the needs and challenges. Paper presented at the ISRA Islamic Finance Seminar.

Yaacob, H. (2012). Issues and challenges of shari'ah audit in Islamic financial institutions: a contemporary view. Paper presented at the Proceedings of 3rd International Conference on Business and Economics Research.

Yaacob, H., \& Donglah, N. K. (2012). Shari'ah Audit in Islamic Financial Institutions: The Postgraduates' Perspective. International Journal of Economics and Finance, 4(12), 224.

Yahya, Y., \& Mahzan, N. (2012). The role of internal auditing in ensuring governance in Islamic financial institution (IFI). Paper presented at the 3rd International Conference on Business and Economic Research (3rd ICBER 2012), Bandung, Indonesia. 